\title{
Quality of Life and Disease Impact of Atopic Dermatitis and Psoriasis on Children and Their Families
}

\author{
Chan Ho $\mathrm{Na}^{1}{ }^{\mathbb{D}}$, Janice Chung ${ }^{2}$ and Eric L. Simpson ${ }^{3, *}$ \\ 1 Department of Dermatology, College of Medicine, Chosun University, Gwangju 61453, Korea; \\ chna@chosun.ac.kr \\ 2 School of Medicine, Creighton University, Omaha, NE 68102, USA; JaniceChung@creighton.edu \\ 3 Department of Dermatology, Oregon Health \& Science University, Portland, OR 97239-4501, USA \\ * Correspondence: simpsone@ohsu.edu; Tel.: +1-503-494-2121
}

Received: 17 September 2019; Accepted: 25 November 2019; Published: 2 December 2019

\begin{abstract}
Atopic dermatitis (AD) and psoriasis are common chronic skin diseases affecting children. These disorders negatively impact the quality of life (QoL) of patients in health-related aspects such as physical, psychosocial, and mental functioning. This health impact is more accurately represented when accounting for the numerous comorbidities associated with each disorder, and the impact the disorders have on patients' families. A number of QoL tools have been developed and can be routinely implemented in the evaluation of QoL in pediatric patients and their caregivers. Ways to improve QoL include a multidisciplinary approach to care, education, and psychological support.
\end{abstract}

Keywords: atopic dermatitis; psoriasis; quality of life; QoL tools; multidisciplinary approach; education; psychological support

\section{Introduction}

Atopic dermatitis (AD) and psoriasis are common cutaneous diseases among children. AD is a chronic pruritic inflammatory skin disease that often presents as ill-defined, erythematous weeping or crusted, papules and/or plaques, and is frequently accompanied by a personal or family history of type I allergies, asthma, and allergic rhinitis [1]. It affects up to $17.5 \%$ of children worldwide, $11 \%$ of children in the US [2,3], and approximately one-third of children with AD have a moderate-to-severe disease [4]. A variety of factors, including skin barrier defects, reduction in antimicrobial peptides, dysfunctional innate immune response, and Th2-skewed skin and systemic inflammation are implicated in the pathogenesis of $\mathrm{AD}$ [5]. Itch is the main symptom of $\mathrm{AD}$ that can lead to frequent scratching, painful skin, loss of sleep, and skin infections [1,6].

Like AD, psoriasis carries a genetic predisposition and typically presents as well-demarcated, salmon-colored plaques with flaky, silvery-white scales. Differentiating between pediatric psoriasis and $\mathrm{AD}$ is usually straightforward clinically with no specific testing required (Table 1). Psoriasis is much less prevalent in children than $\mathrm{AD}$ with the estimated prevalence of childhood psoriasis varying from $0 \%$ to $1.37 \%$ globally. Psoriasis often first appears between the ages of 15 and 35, however, about a third of patients developed the condition during the first two decades, and 10-15\% reported onset before age 10 [7-9]. It is a chronic relapsing inflammatory disease triggered by the expression of Th17 and TNF/IL-17 synergistic cytokines primarily [10]. Patients with psoriasis often describe their pruritus as a stinging or burning sensation, and this itch has been reported to be the most bothersome symptom in about $60-90 \%$ of patients $[11,12]$.

In recent decades, the medical and scientific community is better recognizing the importance of assessing the quality of life (QoL) impact medical conditions have on patients. While QoL is a broad 
concept including standard of living, community, and family life, health-related QoL (HRQoL) is a multidimensional construct including emotional, physical, social, and functional well-being related to health, particularly within chronic diseases. An already large and growing body of literature concludes that both AD and psoriasis profoundly impact the HRQoL of affected children and their families, especially in more moderate to severe disease [13-15]. Thus, the assessment of HRQoL is very important in these diseases as it supplements the conventional clinical exam or scoring systems, captures the effects of the illness on patients and their families, and further measures whether a treatment is actually effective [16,17].

Table 1. Clinical manifestations of atopic dermatitis (AD) and psoriasis.

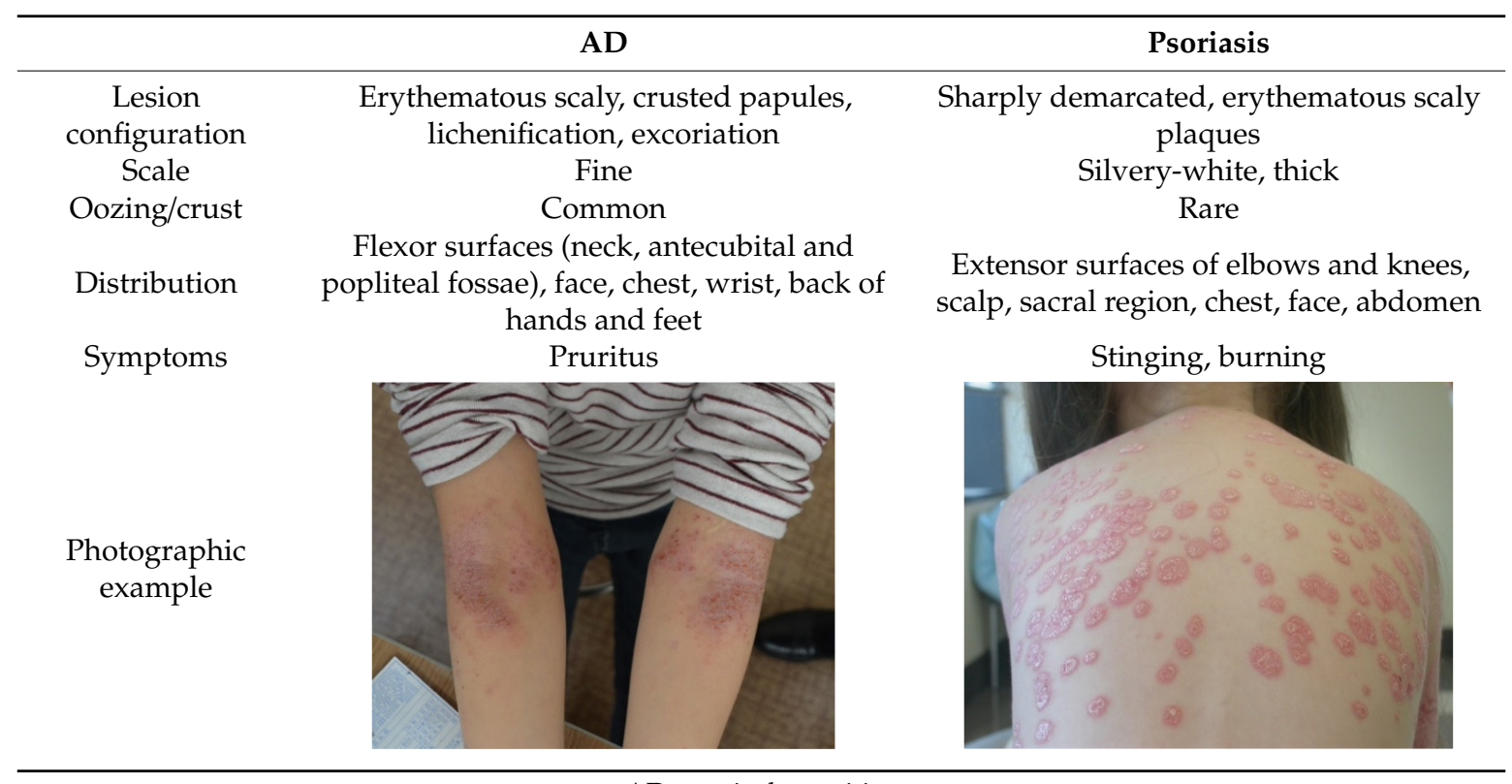

$\mathrm{AD}$, atopic dermatitis.

\section{Measurement of QoL}

Several studies reveal that provider-based assessments do not correlate well with patient-reported QoL assessments emphasizing the need for formal QoL assessments in the clinic to better understand the patient perspective of their disease. There are a variety of different instruments at the provider's disposal to facilitate the measurement of QoL, including dermatology-specific and disease-specific QoL measures (Table 2). While dermatology-specific QoL scales are applicable in all cutaneous diseases and allow for comparisons across different skin diseases, disease-specific QoL instruments focus on specific patterns of a certain disease, which can provide much better insight into its particular characteristics, as well as direct ways to improve QoL $[17,18]$. These tools vary widely with respect to the age of target populations, domains assessed, and scoring algorithms.

QoL tools are usually classified as self-reported (for older children and adolescents) or proxy-reported (for infants and younger children) depending on the ages of the respondents. Cartoon versions (e.g., cartoon version of CDLQI [19]) for young children are becoming increasingly popular [17]. Regular use of these assessments in patients with chronic dermatitis has been recommended because not only can they be used to assess QoL and better understand the patient perspective and impact of the disease, but they can also be used to measure the beneficial effects of treatment [1,20-23].

In clinical trials of skin disease, both dermatology-specific QoL tools (such as the Dermatology Life Quality Index (DLQI), the Children's Dermatology Life Quality Index (CDLQI), the Infants' Dermatitis Quality of Life Index (IDQoL)) and disease-specific QoL tools (such as the Dermatitis Family Index (DFI), the Childhood Atopic Dermatitis Impact Scale (CADIS)) have been commonly used in measuring pediatric and family QoL [1,24-27]. Recently, the Harmonising Outcome Measures for Eczema (HOME) initiative 
identified QoL as an essential domain to be measured in all clinical trials in AD [28]. An April 2019 consensus conference by the HOME initiative identified and recommended that the following instruments should be included in all trials of AD: DLQI (adults), CDLQI (children), and IDQoL (infants) [29].

Table 2. Instruments to assess health-related quality of life (HRQoL) of pediatric patients and their parents/caregivers.

\begin{tabular}{|c|c|c|}
\hline \multirow{2}{*}{ Dermatology-Specific Tools } & \multicolumn{2}{|l|}{ Disease-Specific Tools } \\
\hline & $\mathrm{AD}$ & Psoriasis \\
\hline $\begin{array}{l}\text { - Dermatology Life Quality Index } \\
\text { (DLQI) [30] } \\
\text { - Children's Dermatology Life } \\
\text { Quality Index (CDLQI) [24] } \\
\text { - Infants' Dermatitis Quality of Life } \\
\text { Index (IDQoL) [25] } \\
\text { - Family Dermatology Life Quality } \\
\text { Index (FDLQI) [31] } \\
\text { - Skindex-Teen [32] } \\
\text { - Toddler Quality of Life Survey [33] }\end{array}$ & $\begin{array}{l}\text { - Dermatitis Family Index (DFI) [13] } \\
\text { - Childhood Atopic Dermatitis Impact Scale (CADIS) [34] } \\
\text { - Childhood Impact of Atopic Dermatitis (CIAD) [35] } \\
\text { - DISABKIDS Atopic Dermatitis Module } \\
\text { (DISABKIDS-ADM) [36] } \\
\text { - Parents' Index of Quality of Life in Atopic Dermatitis } \\
\text { (PIQoL-AD) [37] } \\
\text { - Quality of Life in Primary Caregivers of children with } \\
\text { Atopic Dermatitis (QPCAD) [38] } \\
\text { - The Quality of Life in Parents of Children with Atopic } \\
\text { Dermatitis [39] }\end{array}$ & $\begin{array}{l}\text { - Children's } \\
\text { Scalpdex in } \\
\text { Psoriasis [40] }\end{array}$ \\
\hline
\end{tabular}

HRQoL, health-related quality of life; $\mathrm{AD}$, atopic dermatitis.

\section{Disease Impact of AD}

\subsection{AD Impact Relative to Other Diseases}

AD impacts childhood HRQoL to a greater extent than many other chronic cutaneous diseases including urticaria, alopecia, acne, and localized eczema. AD was found to be equivalent in impact to other non-dermatologic chronic childhood disorders and only second to cerebral palsy [14]. It has been suggested that raising a child with AD could be more impactful to the family than raising a child with type I diabetes [41].

Itch and sleep-related deficits are closely associated with QoL of AD. Children can become irritable and inattentive when experiencing severe pruritus, and parents often find it difficult to keep their child from scratching [42]. Additionally, pruritus is highly associated with sleep disturbance, which has been estimated to affect as much as $60 \%$ of children or $83 \%$ of children with flares [43]. The effects of such sleep disturbance include decreased sleep efficiency from waking up throughout the night, trouble getting to sleep, reduced total sleep time, difficulty waking up, as well as daytime drowsiness and irritability [44]. Sleep disturbance does not simply affect children with AD, but also their family members who might have to provide medications or reassurance during the night, or from being awakened while cosleeping [45].

\subsection{Psychosocial/Mental Comorbidity}

There has been increasing evidence of the elevated risk of developing psychosocial and mental comorbid diseases in childhood $\mathrm{AD}[46,47]$. According to the available literature, psychological comorbidities were more prevalent in children with AD than those with leukemia or epilepsy [48]. Mental and emotional sequelae, including cognitive and functional impairment, as well as behavioral problems often extend far beyond the actual physical manifestations, especially in patients with severe disease [49-51]. Psychosocial abnormalities of children with AD appear in various ways. Behavioral and maladjustment problems, sibling rivalry, abnormal psychological development, childhood low self-esteem, and lack of socialization skills were all reported [41]. Children with AD also showed excessive dependency, clinginess, and fearfulness [52]. Damaged social functioning results in missing outdoor activity or avoiding outside work altogether [53]. Emotional and physical fatigue owing to chronic sleep loss may negatively affect social relationships and QoL of the adolescent AD patient, leading to an increased risk of depression and anxiety [54]. A cross-sectional study analyzing data from 
92,642 US children reported that children with AD had increased risk of attention-deficit hyperactivity disorder (ADHD), depression, anxiety, conduct disorder, and autism [55]. Such disorders can continue or become exacerbated when the child's AD remits [56].

Having AD appears to increase the risk of suicide and suicidal ideation. One study of Korean adolescents with $\mathrm{AD}$ found a significantly larger risk of suicide and suicidal ideation compared to adolescents without the disease, while another study from Korea showed a significant association between atopic dermatitis and suicidal behaviors for girls [57,58]. A meta-analysis confirmed this increased risk of suicidal ideation in children and adults with AD compared with healthy controls [59].

High levels of anxiety and depression have also been found in parents of a chronically ill child, especially mothers [60]. In particular, childhood AD negatively impacts maternal physical and mental wellbeing [61]. Parents often experience exhaustion, frustration, helplessness, feelings of guilt, sleep deprivation, and instability of spousal and other familial relationships [41,53]. They also have more absences from work, poor social activities, stress about child care, and challenges related to discipline than parents without chronically ill children [46]. When it comes to management of AD, many worries are related to disease triggers and medication use, including fear of using topical corticosteroids [62].

\subsection{Impact of Comorbidities on QoL}

Patients with moderate to severe AD have a greater risk of having comorbid asthma, hay fever, food allergies, cutaneous infections and possibly cardio-metabolic comorbidities, each of which may negatively impact QoL [63,64]. A number of concurrent atopic conditions (e.g., food allergy, allergic rhinitis, asthma) and severity of the child's AD are related proportionally to the likelihood of psychological comorbidity [65]. Shorter stature, delayed growth, and early childhood obesity have been documented as possible physical comorbidities, particularly in children with severe AD [66-68].

\section{Disease Impact of Psoriasis}

\subsection{Psoriasis Impact Relative to Other Diseases}

Children with psoriasis are negatively impacted in their educational, physical, emotional, and social wellbeing in comparison to their healthy peers [69]. Their overall QoL impairments are significantly greater than those in children with epilepsy, enuresis, diabetes, and vitiligo [14,70]. The HRQoL of children with moderate-to-severe psoriasis is similar to that of their peers suffering from chronic disorders including arthritis and asthma, although pediatric psychiatric disorders cause the most impairment $[15,71]$. Children with psoriasis commonly experience itching, which causes considerable daily impairment and sleep disturbance, albeit to a lesser extent than that of adolescents with AD and adults with psoriasis [72-75].

\subsection{Psychosocial/Mental Comorbidity}

While there are a number of studies on the psychological and mental wellbeing of adults with psoriasis, there has not been much literature regarding children with psoriasis. A retrospective study of 61 pediatric psoriasis patients reported concurrent emotional stress (54\%) and psychiatric morbidity (9.8\%) [76]. Additionally, pediatric patients with psoriasis were shown to have an approximately $25 \%$ to $30 \%$ greater risk of developing psychiatric disorders such as depression and/or anxiety versus children without psoriasis [77]. Anxiety or depression may stem from experiences of embarrassment, shame, behavior avoidance, teasing, bullying, stigmatization, disrupted body image, decrease in self-confidence, and social isolation, resulting in some patients being prescribed psychotropic medications [77-79]. Psoriasis beginning in child or teenage years has been associated with more frequently developing flares in times of stress or trauma, and might be associated with higher disease severity and psychological comorbidities $[80,81]$. As many as $90 \%$ of children report psoriasis flares with stress, and having visible or severe lesions may cause further stress, potentially exacerbating the disease process itself in an escalating biopsychosocial cycle $[81,82]$. 
While mood disturbances such as feeling upset or sad as measured by parent-report in young children are severely impacted, adolescents find that appearance-related concerns, that is, 'being on display,' are more problematic $[72,83]$. Notably, adolescents with new-onset psoriasis may not be comfortable with their new appearance, which could lead to future impairment of HRQoL, such as the development of intimacy issues [84].

Although there are only a few studies for suicidality in children with psoriasis, several studies have reported that younger patients with psoriasis have a greater likelihood of experiencing suicidality than older patients [85]. Thus, it is essential for physicians to identify psoriatic patients of all ages who may be at risk for suicidal ideation and behavior.

Ninety percent of family members of adults with psoriasis responded that the patient affects their own QoL [86]. One study noted that parents of children with psoriasis are adversely impacted in their QoL in aspects such as emotional and personal wellbeing, functioning within the family and society, and life pursuits [15]. In the study, participating parents responded that their child's psoriasis particularly caused a substantial impact on their emotional well-being as concerns about their child were a source of stress, sadness, frustration, and depressed mood.

\subsection{Impact of Comorbidities on QoL}

Children with psoriasis have an increased risk of concomitant obesity, hypertension, heart disease, diabetes, and autoimmune disorders such as rheumatoid arthritis and Crohn's disease, all of which may subsequently negatively impact QoL $[87,88]$. Psoriasis and obesity are both socially stigmatizing. The stigma surrounding psoriasis may cause patients to become embarrassed and have low self-esteem, and poor coping mechanisms may lead to avoidance of social situations, eating in excess, forgoing activity, and developing or worsening obesity. Therefore, pediatric psoriasis and its increased risk of obesity can contribute to the exacerbation of one another and overall decrease patient QoL [89,90].

\section{Strategies to Improve QoL}

The routine use of proper QoL questionnaires can be an effective tool in early assessment and intervention of treatment effects. Despite the advent of many new QoL evaluation tools for chronic pediatric $\mathrm{AD}$, most were poorly validated and generally unavailable for use in routine clinical practice. Further validation studies and continued development of new QoL scales focused on feasibility for clinical practice are necessary. No QoL instrument has been endorsed by the HOME group for use in clinical practice yet, but the DLQI, IDQoL, and CDLQI instruments have been endorsed for clinical trials and given limited items on these questionnaires, they may be suitable for clinical practice. The Skindex-16 or Skindex-mini, which investigate the symptomatic, emotional, and functional aspects of an individual's skin disorder, may also be suitable for clinical practice with the latter having only three questions [91]. Furthermore, given the growing knowledge of suicidal ideation and behavior in these dermatologic diseases, there is a need to develop and apply feasible psychiatric screening tools for this population as a preventative measure in the near future.

A multidisciplinary approach, including communication and collaboration between primary care providers, dermatologists, psychiatrists, pediatric specialists, nurses, social workers, nutritionists, and support groups, is essential for long-term control of these disorders, especially when psychological support is needed [92-95]. The team should educate the patients and their families on their diseases, with focuses on the chronic relapsing nature and difficulties inherent to the disease, preventative treatment, and control of acute exacerbations, and the necessities of frequent monitoring and psychological support. So-called "therapeutic patient education" helps patients and their caregivers better understand their condition and its treatment, leading to improvement of QoL and adherence to therapy; therefore, it should be provided particularly to patients and families who have experienced treatment failures or feel a lack of social support [96]. Physicians should also refer to a mental health specialist when necessary, and explain possible comorbidities to the patient as part of the management plan [1]. 
In recent decades, eczema schools consisting of structured age-related group training programs regarding practical tips of management of $\mathrm{AD}$ such as medical information, skincare, and coping with psychosocial problems, have been effectively implemented throughout Germany. Given their success, these schools are now being adopted in several countries, including Japan, Denmark, and the US [97-99]. Italian researchers compared conventional treatment of AD to treatment with the addition of regular educational programs; supplementation with reinforced education led to decreased levels of anxiety in the family and fostered interaction among the children, parents, and physicians [95]. Dutch researchers testing multidisciplinary training programs for 15 children with psoriasis and their parents reported improved patient QoL, reduced pruritus and scratching, strengthened illness awareness, diminished impact on family life, and decreased disease severity [92].

The participation in support groups such as the National Eczema Association, National Psoriasis Foundation, and online relevant forums should also be recommended. Such groups can enhance the multidisciplinary approach as they offer opportunities to exchange experiences among attendants, thereby enlightening others regarding the complexity of the disease and helping other individuals who face similar problems [100]. In particular, online forums may be helpful because anonymity allows individuals to express their feelings freely while eliminating the stress of appearance [101].

\section{Conclusions}

Overall, chronic childhood diseases such as AD and psoriasis can have a detrimental impact on social, personal, and emotional perspectives of QoL of patients and their parents (Table 3). Providers should routinely ask patients about how their skin disease impacts their quality of life, specifically how the disease affects sleep, social relationships, mood, and school. This provides a better understanding of the patients and helps guide the shared-decision-making process. Validated instruments designed to assess QoL of patients provide an additional level of understanding of a patient's condition and allows for a standardized longitudinal assessment of therapeutic effects. The multidisciplinary approach, including participation in support groups, may lead to an enhanced understanding of the disease and therefore may improve QoL. Additional development and evaluation of more practical QoL scales to explore treatment efficacy, as well as additional support strategies for pediatric patients and their families, are needed.

Table 3. Disease impacts of AD and psoriasis in children.

\begin{tabular}{|c|c|c|}
\hline & $\mathrm{AD}$ & Psoriasis \\
\hline $\begin{array}{l}\text { Overall QoL } \\
\text { impairment }\end{array}$ & $\begin{array}{l}\text { - Greatest negative impact on HRQoL among chronic } \\
\text { skin disorders including urticaria, alopecia, acne, and } \\
\text { localized eczema [14] }\end{array}$ & $\begin{array}{l}\text { - Greater negative impact than } \\
\text { those seen in children with } \\
\text { epilepsy, enuresis, diabetes, and } \\
\text { vitiligo }[14,70] \\
\text { - Comparable impairment to those } \\
\text { seen in children with other chronic } \\
\text { diseases such as arthritis or } \\
\text { asthma }[15,71]\end{array}$ \\
\hline $\begin{array}{l}\text { Itch and sleep } \\
\text { disturbance }\end{array}$ & $\begin{array}{l}\text { - Frequent scratching due to itching [42] } \\
\text { - Decreased sleep efficiency, trouble getting to sleep, } \\
\text { reduced total sleep time, difficulty waking up, daytime } \\
\text { drowsiness, and irritability }[43,44]\end{array}$ & $\begin{array}{l}\text { - Itching frequently [72-74] } \\
\text { - Disturbed sleep due to pruritus } \\
\text { and pain [75] }\end{array}$ \\
\hline $\begin{array}{l}\text { Psychosocial/mental } \\
\text { comorbidities }\end{array}$ & $\begin{array}{l}\text { - Behavioral and maladjustment problems, sibling } \\
\text { rivalry, abnormal psychological development, } \\
\text { childhood low self-esteem, and lack of socialization } \\
\text { skills [41], excessive dependency, clinginess, } \\
\text { fearfulness [52], and damaged social functioning [53] } \\
\text { - Increased risk of ADHD, depression, anxiety, conduct } \\
\text { disorder, and autism [55] }\end{array}$ & $\begin{array}{l}\text { - Embarrassment, shame, behavior } \\
\text { avoidance, teasing, bullying, } \\
\text { stigmatization, disrupted body } \\
\text { image, decrease in self-confidence, } \\
\text { and social isolation [77-79] } \\
\text { - Increased risk of anxiety and } \\
\text { depression [77] }\end{array}$ \\
\hline
\end{tabular}


Table 3. Cont.

\begin{tabular}{|c|c|c|}
\hline & $\mathrm{AD}$ & Psoriasis \\
\hline Comorbidities & $\begin{array}{l}\text { - Comorbid asthma, hay fever, food allergies, } \\
\text { cutaneous infections, and possibly cardio-metabolic } \\
\text { comorbidities }[63,64] \\
\text { - Shorter stature, delayed growth, and early childhood } \\
\text { obesity [66-68] }\end{array}$ & $\begin{array}{l}\text { - Increased risk of concomitant } \\
\text { obesity, hypertension, heart } \\
\text { disease, diabetes, and } \\
\text { autoimmune disorders [87-90] }\end{array}$ \\
\hline $\begin{array}{l}\text { Impact for } \\
\text { caregivers and } \\
\text { family }\end{array}$ & $\begin{array}{l}\text { - Greater impact than having a child with type } 1 \\
\text { diabetes [41] } \\
\text { - Sleep deprivation [45], anxiety, depression [60], } \\
\text { exhaustion, frustration, helplessness, feelings of guilt, } \\
\text { and instability of spousal and other familial } \\
\text { relationships [41,53] }\end{array}$ & $\begin{array}{l}\text { - Adverse impact on emotional } \\
\text { well-being including stress, } \\
\text { sadness, frustration, and } \\
\text { depressed mood [15] }\end{array}$ \\
\hline
\end{tabular}

$\mathrm{AD}$, atopic dermatitis; ADHD, attention-deficit hyperactivity disorder.

Author Contributions: C.H.N. and E.L.S. conceived of the concepts discussed in this review. C.H.N. crafted the original draft of the manuscript. All authors contributed to the writing and editing of the manuscript.

Funding: This research received no external funding.

Conflicts of Interest: The authors declare no conflicts of interest.

\section{References}

1. Eichenfield, L.F.; Tom, W.L.; Chamlin, S.L.; Feldman, S.R.; Hanifin, J.M.; Simpson, E.L.; Berger, T.G.; Bergman, J.N.; Cohen, D.E.; Cooper, K.D.; et al. Guidelines of care for the management of atopic dermatitis: Section 1. Diagnosis and assessment of atopic dermatitis. J. Am. Acad. Dermatol. 2014, 70, 338-351. [CrossRef] [PubMed]

2. Williams, H.; Stewart, A.; von Mutius, E.; Cookson, W.; Anderson, H.R.; International Study of Asthma. Is eczema really on the increase worldwide? J. Allergy Clin. Immunol. 2008, 121, 947-954.e915. [CrossRef] [PubMed]

3. Shaw, T.E.; Currie, G.P.; Koudelka, C.W.; Simpson, E.L. Eczema prevalence in the United States: Data from the 2003 National Survey of Children's Health. J. Investig. Dermatol. 2011, 131, 67-73. [CrossRef] [PubMed]

4. Silverberg, J.I.; Simpson, E.L. Associations of childhood eczema severity: A US population based study. Dermat. Contact Atopic Occup. Drug 2014, 25, 107. [CrossRef] [PubMed]

5. Kuo, I.-H.; Yoshida, T.; De Benedetto, A.; Beck, L.A. The cutaneous innate immune response in patients with atopic dermatitis. J. Allergy Clin. Immunol. 2013, 131, 266-278. [CrossRef] [PubMed]

6. Koblenzer, C.S. Itching and the atopic skin. J. Allergy Clin. Immunol. 1999, 104, S109-S113. [CrossRef]

7. Tollefson, M.M.; Crowson, C.S.; McEvoy, M.T.; Kremers, H.M. Incidence of psoriasis in children: A population-based study. J. Am. Acad. Dermatol. 2010, 62, 979-987. [CrossRef]

8. Michalek, I.; Loring, B.; John, S. A systematic review of worldwide epidemiology of psoriasis. J. Eur. Acad. Dermatol. Venereol. 2017, 31, 205-212. [CrossRef]

9. Farber, E.M.; Nall, L. The natural history of psoriasis in 5600 patients. Dermatology 1974, 148, 1-18. [CrossRef]

10. Guttman-Yassky, E.; Nograles, K.E.; Krueger, J.G. Contrasting pathogenesis of atopic dermatitis and psoriasis-Part II: Immune cell subsets and therapeutic concepts. J. Allergy Clin. Immunol. 2011, 127, 1420-1432. [CrossRef]

11. Prignano, F.; Ricceri, F.; Pescitelli, L.; Lotti, T. Itch in psoriasis: Epidemiology, clinical aspects and treatment options. Clin. Cosmet. Investig. Dermatol. CCID 2009, 2, 9. [CrossRef] [PubMed]

12. Szepietowski, J.; Reich, A. Pruritus in psoriasis: An update. Eur. J. Pain 2016, 20, 41-46. [CrossRef] [PubMed]

13. Lawson, V.; Lewis-Jones, M.S.; Finlay, A.Y.; Reid, P.; Owens, R.G. The family impact of childhood atopic dermatitis: The Dermatitis Family Impact Questionnaire. Br. J. Dermatol. 1998, 138, 107-113. [CrossRef] [PubMed]

14. Beattie, P.; Lewis-Jones, M. A comparative study of impairment of quality of life in children with skin disease and children with other chronic childhood diseases. Br. J. Dermatol. 2006, 155, 145-151. [CrossRef]

15. Tollefson, M.M.; Finnie, D.M.; Schoch, J.J.; Eton, D.T. Impact of childhood psoriasis on parents of affected children. J. Am. Acad. Dermatol. 2017, 76, 286-289.e285. [CrossRef]

16. Lifschitz, C. The impact of atopic dermatitis on quality of life. Ann. Nutr. Metab. 2015, 66, 34-40. [CrossRef] 
17. Do Amaral, C.S.F.; March, M.d.F.B.P.; Sant'Anna, C.C. Instruments that measure the quality of life in atopic dermatitis among children and adolescents. Clin. Investig. 2013, 3, 935-942. [CrossRef]

18. Augustin, M.; Langenbruch, A.K.; Gutknecht, M.; Radtke, M.A.; Blome, C. Quality of life measures for dermatology: Definition, evaluation, and interpretation. Curr. Dermatol. Rep. 2012, 1, 148-159. [CrossRef]

19. Holme, S.; Man, I.; Sharpe, J.; Dykes, P.; Lewis-Jones, M.; Finlay, A. The Children's Dermatology Life Quality Index: Validation of the cartoon version. Br. J. Dermatol. 2003, 148, 285-290. [CrossRef]

20. Neri, E.; Agostini, F.; Gremigni, P.; Gobbi, F.; Casu, G.; Chamlin, S.L.; Monti, F. Italian validation of the Childhood Atopic Dermatitis Impact Scale: A contribution to its clinical application. J. Investig. Dermatol. 2012, 132, 2534-2543. [CrossRef]

21. McKenna, S.P.; Doward, L.C. Quality of life of children with atopic dermatitis and their families. Curr. Opin. Allergy Clin. Immunol. 2008, 8, 228-231. [CrossRef] [PubMed]

22. Halioua, B.; Beumont, M.G.; Lunel, F. Quality of life in dermatology. Int. J. Dermatol. 2000, 39, 801-806. [CrossRef] [PubMed]

23. Chernyshov, P.; Tomas-Aragones, L.; Manolache, L.; Marron, S.; Salek, M.; Poot, F.; Oranje, A.; Finlay, A.Y.; EADV Quality of Life Task Force. Quality of life measurement in atopic dermatitis. Position paper of the European Academy of Dermatology and Venereology (EADV) Task Force on quality of life. J. Eur. Acad. Derm. Venereol. 2017, 31, 576-593. [CrossRef] [PubMed]

24. Lewis-Jones, M.; Finlay, A. The Children's Dermatology Life Quality Index (CDLQI): Initial validation and practical use. Br. J. Dermatol. 1995, 132, 942-949. [CrossRef] [PubMed]

25. Lewis-Jones, M.; Finlay, A.; Dykes, P. The infants' dermatitis quality of life index. Br. J. Dermatol. 2001, 144, 104-110. [CrossRef] [PubMed]

26. Heinl, D.; Prinsen, C.; Sach, T.; Drucker, A.; Ofenloch, R.; Flohr, C.; Apfelbacher, C. Measurement properties of quality-of-life measurement instruments for infants, children and adolescents with eczema: A systematic review. Br. J. Dermatol. 2017, 176, 878-889. [CrossRef] [PubMed]

27. Rehal, B.; Armstrong, A. Health outcome measures in atopic dermatitis: A systematic review of trends in disease severity and quality-of-life instruments 1985-2010. PLoS ONE 2011, 6, e17520. [CrossRef]

28. Schmitt, J.; Apfelbacher, C.; Spuls, P.I.; Thomas, K.S.; Simpson, E.L.; Furue, M.; Chalmers, J.; Williams, H.C. The Harmonizing Outcome Measures for Eczema (HOME) roadmap: A methodological framework to develop core sets of outcome measurements in dermatology. J. Investig. Dermatology 2015, 135, 24-30. [CrossRef]

29. HOME VII Meeting. HOME-Harmonising Outcome Measures for Eczema. Available online: www. homeforeczema.org (accessed on 10 April 2019).

30. Finlay, A.Y.; Khan, G. Dermatology Life Quality Index (DLQI)-A simple practical measure for routine clinical use. Clin. Exp. Dermatol. 1994, 19, 210-216. [CrossRef]

31. Basra, M.; Sue-Ho, R.; Finlay, A. The Family Dermatology Life Quality Index: Measuring the secondary impact of skin disease. Br. J. Dermatol. 2007, 156, 528-538. [CrossRef]

32. Smidt, A.C.; Lai, J.-S.; Cella, D.; Patel, S.; Mancini, A.J.; Chamlin, S.L. Development and validation of Skindex-Teen, a quality-of-life instrument for adolescents with skin disease. Arch. Dermatol. 2010, 146, 865-869. [CrossRef] [PubMed]

33. Drake, L.; Prendergast, M.; Maher, R.; Breneman, D.; Korman, N.; Satoib, Y.; Beusterien, K.M.; Lawrence, I. The impact of tacrolimus ointment on health-related quality of life of adult and pediatric patients with atopic dermatitis. J. Am. Acad. Dermatol. 2001, 44, S65-S72. [CrossRef] [PubMed]

34. Chamlin, S.L.; Lai, J.-S.; Cella, D.; Frieden, I.J.; Williams, M.L.; Mancini, A.J.; Chren, M.-M. Childhood Atopic Dermatitis Impact Scale: Reliability, discriminative and concurrent validity, and responsiveness. Arch. Dermatol. 2007, 143, 768-772. [CrossRef] [PubMed]

35. McKenna, S.P.; Doward, L.C.; Meads, D.M.; Tennant, A.; Lawton, G.; Grueger, J. Quality of life in infants and children with atopic dermatitis: Addressing issues of differential item functioning across countries in multinational clinical trials. Health Qual. Life Outcomes 2007, 5, 45. [CrossRef]

36. Baars, R.M.; Atherton, C.I.; Koopman, H.M.; Bullinger, M.; Power, M. The European DISABKIDS project: Development of seven condition-specific modules to measure health related quality of life in children and adolescents. Health Qual. Life Outcomes 2005, 3, 70. [CrossRef]

37. McKenna, S.P.; Whalley, D.; Dewar, A.L.; Erdman, R.A.; Kohlmann, T.; Niero, M.; Baró, E.; Cook, S.A.; Crickx, B.; Frech, F. International development of the parents' index of quality of life in atopic dermatitis (PIQoL-AD). Qual. Life Res. 2005, 14, 231-241. [CrossRef] 
38. Kondo-Endo, K.; Ohashi, Y.; Nakagawa, H.; Katsunuma, T.; Ohya, Y.; Kamibeppu, K.; Masuko, I. Development and validation of a questionnaire measuring quality of life in primary caregivers of children with atopic dermatitis (QPCAD). Br. J. Dermatol. 2009, 161, 617-625. [CrossRef]

39. Von Rüden, U.; Staab, D.; Kehrt, R.; Wahn, U. Entwicklung und Validierung eines krankheitsspezifischen Fragebogens zur Erfassung der Lebensqualität von Eltern neurodermitiskranker Kinder. Z. Gesundh. J. Public Health 1999, 7, 335. [CrossRef]

40. Oostveen, A.M.; De Jong, E.M.; Evers, A.W.; Donders, A.; De Van Kerkhof, P.; Seyger, M. Reliability, responsiveness and validity of Scalpdex in children with scalp psoriasis: The Dutch study. Acta Derm. Venereol. 2014, 94, 198-202. [CrossRef]

41. Su, J.C.; Kemp, A.S.; Varigos, G.A.; Nolan, T.M. Atopic eczema: Its impact on the family and financial cost. Arch. Dis. Child. 1997, 76, 159-162. [CrossRef]

42. Elliott, B.E.; Luker, K. The experiences of mothers caring for a child with severe atopic eczema. J. Clin. Nurs. 1997, 6, 241-247. [CrossRef] [PubMed]

43. Camfferman, D.; Kennedy, J.D.; Gold, M.; Martin, A.J.; Lushington, K. Eczema and sleep and its relationship to daytime functioning in children. Sleep Med. Rev. 2010, 14, 359-369. [CrossRef] [PubMed]

44. Stores, G.; Burrows, A.; Crawford, C. Physiological sleep disturbance in children with atopic dermatitis: A case control study. Pediatric Dermatol. 1998, 15, 264-268. [CrossRef] [PubMed]

45. Chamlin, S.L.; Mattson, C.L.; Frieden, I.J.; Williams, M.L.; Mancini, A.J.; Cella, D.; Chren, M.-M. The price of pruritus: Sleep disturbance and cosleeping in atopic dermatitis. Arch. Pediatrics Adolesc. Med. 2005, 159, 745-750. [CrossRef]

46. Daud, L.; Garralda, M.; David, T. Psychosocial adjustment in preschool children with atopic eczema. Arch. Dis. Child. 1993, 69, 670-676. [CrossRef]

47. Mitchell, A.E.; Fraser, J.A.; Morawska, A.; Ramsbotham, J.; Yates, P. Parenting and childhood atopic dermatitis: A cross-sectional study of relationships between parenting behaviour, skin care management, and disease severity in young children. Int. J. Nurs. Stud. 2016, 64, 72-85. [CrossRef]

48. Absolon, C.; Cottrell, D.; Eldridge, S.; Glover, M. Psychological disturbance in atopic eczema: The extent of the problem in school-aged children. Br. J. Dermatol. 1997, 137, 241-245. [CrossRef]

49. Bullinger, M.; Schmidt, S.; Petersen, C.; DISABKIDS group. Assessing quality of life of children with chronic health conditions and disabilities: A European approach. Int. J. Rehabil. Res. 2002, 25, 197-206. [CrossRef]

50. Holm, E.A.; Wulf, H.C.; Stegmann, H.; Jemec, G.B. Life quality assessment among patients with atopic eczema. Br. J. Dermatol. 2006, 154, 719-725. [CrossRef]

51. Mozaffari, H.; Pourpak, Z.; Pourseyed, S.; Farhoodi, A.; Aghamohammadi, A.; Movahadi, M.; Gharaghozloo, M.; Moin, M. Quality of life in atopic dermatitis patients. J. Microbiol. Immunol. Infect. Wei Mian Yu Gan Ran Za Zhi 2007, 40, 260-264.

52. Chamlin, S.L.; Frieden, I.J.; Williams, M.L.; Chren, M.-M. Effects of atopic dermatitis on young American children and their families. Pediatrics 2004, 114, 607-611. [CrossRef] [PubMed]

53. Lapidus, C.; Kerr, P. Social impact of atopic dermatitis. Med. Health 2001, 84, 294-295.

54. Slattery, M.J.; Essex, M.J.; Paletz, E.M.; Vanness, E.R.; Infante, M.; Rogers, G.M.; Gern, J.E. Depression, anxiety, and dermatologic quality of life in adolescents with atopic dermatitis. J. Allergy Clin. Immunol. 2011, 128, 668. [CrossRef] [PubMed]

55. Yaghmaie, P.; Koudelka, C.W.; Simpson, E.L. Mental health comorbidity in patients with atopic dermatitis. J. Allergy Clin. Immunol. 2013, 131, 428-433. [CrossRef] [PubMed]

56. Schmitt, J.; Apfelbacher, C.; Chen, C.-M.; Romanos, M.; Sausenthaler, S.; Koletzko, S.; Bauer, C.-P.; Hoffmann, U.; Krämer, U.; Berdel, D. Infant-onset eczema in relation to mental health problems at age 10 years: Results from a prospective birth cohort study (German Infant Nutrition Intervention plus). J. Allergy Clin. Immunol. 2010, 125, 404-410. [CrossRef]

57. Lee, S.; Shin, A. Association of atopic dermatitis with depressive symptoms and suicidal behaviors among adolescents in Korea: The 2013 Korean Youth Risk Behavior Survey. BMC Psychiatry 2017, 17, 3. [CrossRef] [PubMed]

58. Noh, H.-M.; Cho, J.J.; Park, Y.S.; Kim, J.-H. The relationship between suicidal behaviors and atopic dermatitis in Korean adolescents. J. Health Psychol. 2016, 21, 2183-2194. [CrossRef] 
59. Patel, K.R.; Immaneni, S.; Singam, V.; Rastogi, S.; Silverberg, J.I. Association between atopic dermatitis, depression, and suicidal ideation: A systematic review and meta-analysis. J. Am. Acad. Dermatol. 2019, 80, 402-410. [CrossRef]

60. Van Oers, H.A.; Haverman, L.; Limperg, P.F.; van Dijk-Lokkart, E.; Maurice-Stam, H.; Grootenhuis, M. Anxiety and depression in mothers and fathers of a chronically ill child. Matern. Child Health J. 2014, 18, 1993-2002. [CrossRef]

61. Ho, R.C.; Giam, Y.; Ng, T.; Mak, A.; Goh, D.; Zhang, M.W.; Cheak, A.; Van Bever, H.P. The influence of childhood atopic dermatitis on health of mothers, and its impact on Asian families. Pediatric Allergy Immunol. 2010, 21, 501-507. [CrossRef]

62. Charman, C.; Morris, A.; Williams, H. Topical corticosteroid phobia in patients with atopic eczema. Br. J. Dermatol. 2000, 142, 931-936. [CrossRef] [PubMed]

63. Silverberg, J.I.; Gelfand, J.M.; Margolis, D.J.; Boguniewicz, M.; Fonacier, L.; Grayson, M.H.; Simpson, E.L.; Ong, P.Y.; Fuxench, Z.C.C. Patient burden and quality of life in atopic dermatitis in US adults: A populationbased cross-sectional study. Ann. Allergy Asthma Immunol. 2018, 121, 340-347. [CrossRef] [PubMed]

64. Simpson, E.L. Comorbidity in atopic dermatitis. Curr. Dermatol. Rep. 2012, 1, 29-38. [CrossRef] [PubMed]

65. Hammer-Helmich, L.; Linneberg, A.; Obel, C.; Thomsen, S.F.; Møllehave, L.T.; Glümer, C. Mental health associations with eczema, asthma and hay fever in children: A cross-sectional survey. BMJ Open 2016, 6, e012637. [CrossRef] [PubMed]

66. Palit, A.; Handa, S.; Bhalla, A.K.; Kumar, B. A mixed longitudinal study of physical growth in children with atopic dermatitis. Indian J. Dermatol. Venereol. Leprol. 2007, 73, 171. [PubMed]

67. Agostoni, C.; Grandi, F.; Scaglioni, S.; Giannì, M.L.; Torcoletti, M.; Radaelli, G.; Fiocchi, A.; Riva, E. Growth pattern of breastfed and nonbreastfed infants with atopic dermatitis in the first year of life. Pediatrics 2000, 106, e73. [CrossRef] [PubMed]

68. Ellison, J.; Patel, L.; Kecojevic, T.; Foster, P.; David, T.; Clayton, P. Pattern of growth and adiposity from infancy to adulthood in atopic dermatitis. Br. J. Dermatol. 2006, 155, 532-538. [CrossRef]

69. Mitchell, A.E. Bidirectional relationships between psychological health and dermatological conditions in children. Psychol. Res. Behav. Manag. 2018, 11, 289. [CrossRef]

70. Manzoni, A.P.D.d.S.; Pereira, R.L.; Townsend, R.Z.; Weber, M.B.; Nagatomi, A.R.d.S.; Cestari, T.F. Assessment of the quality of life of pediatric patients with the major chronic childhood skin diseases. An. Bras. Dermatol. 2012, 87, 361-368. [CrossRef]

71. Varni, J.W.; Globe, D.R.; Gandra, S.R.; Harrison, D.J.; Hooper, M.; Baumgartner, S. Health-related quality of life of pediatric patients with moderate to severe plaque psoriasis: Comparisons to four common chronic diseases. Eur. J. Pediatrics 2012, 171, 485-492. [CrossRef]

72. Randa, H.; Lomholt, J.; Skov, L.; Zachariae, R. Health-related quality of life in adolescents with psoriasis: An interview-based study. Br. J. Dermatol. 2018, 178, 1404-1411. [CrossRef] [PubMed]

73. De Jager, M.E.; De Jong, E.M.; Evers, A.W.; Van De Kerkhof, P.C.; Seyger, M.M. The burden of childhood psoriasis. Pediatric Dermatol. 2011, 28, 736-737. [CrossRef] [PubMed]

74. Raychaudhuri, S.P.; Gross, J. A comparative study of pediatric onset psoriasis with adult onset psoriasis. Pediatric Dermatol. 2000, 17, 174-178. [CrossRef] [PubMed]

75. Gupta, M.A.; Simpson, F.C.; Gupta, A.K. Psoriasis and sleep disorders: A systematic review. Sleep Med. Rev. 2016, 29, 63-75. [CrossRef] [PubMed]

76. Seyhan, M.; Coşkun, B.K.; Sağlam, H.; Özcan, H.; Karincaoğlu, Y. Psoriasis in childhood and adolescence: Evaluation of demographic and clinical features. Pediatrics Int. 2006, 48, 525-530. [CrossRef] [PubMed]

77. Kimball, A.B.; Wu, E.Q.; Guérin, A.; Andrew, P.Y.; Tsaneva, M.; Gupta, S.R.; Bao, Y.; Mulani, P.M. Risks of developing psychiatric disorders in pediatric patients with psoriasis. J. Am. Acad. Dermatol. 2012, 67, 651-657.e652. [CrossRef] [PubMed]

78. Bilgic, A.; Bilgic, Ö.; Akış, H.K.; Eskioğlu, F.; Kılıç, E.Z. Psychiatric symptoms and health-related quality of life in children and adolescents with psoriasis. Pediatric Dermatol. 2010, 27, 614-617. [CrossRef]

79. Golics, C.; Basra, M.; Finlay, A.; Salek, M. Adolescents with skin disease have specific quality of life issues. Dermatology 2009, 218, 357-366. [CrossRef]

80. Remröd, C.; Sjöström, K.; Svensson, Å. Psychological differences between early-and late-onset psoriasis: A study of personality traits, anxiety and depression in psoriasis. Br. J. Dermatol. 2013, 169, 344-350. [CrossRef] 
81. Basavaraj, K.H.; Navya, M.A.; Rashmi, R. Stress and quality of life in psoriasis: An update. Int. J. Dermatol. 2011, 50, 783-792. [CrossRef]

82. Nyfors, A.; Lemholt, K. Psoriasis in children: A short review and a survey of 245 cases. Br. J. Dermatol. 1975, 92, 437-442. [CrossRef] [PubMed]

83. Gånemo, A.; Wahlgren, C.F.; Svensson, Å. Quality of life and clinical features in Swedish children with psoriasis. Pediatric Dermatol. 2011, 28, 375-379. [CrossRef] [PubMed]

84. Randa, H.; Todberg, T.; Skov, L.; Larsen, L.S.; Zachariae, R. Health-related quality of life in children and adolescents with psoriasis: A systematic review and meta-analysis. Acta Derm. Venereol. 2017, 97, 555-563. [CrossRef] [PubMed]

85. Liang, S.E.; Cohen, J.M.; Ho, R.S. Psoriasis and suicidality: A review of the literature. Dermatol. Ther. 2019, 32, e12771. [CrossRef] [PubMed]

86. Tadros, A.; Vergou, T.; Stratigos, A.; Tzavara, C.; Hletsos, M.; Katsambas, A.; Antoniou, C. Psoriasis: Is it the tip of the iceberg for the quality of life of patients and their families? J. Eur. Acad. Derm. Venereol. 2011, 25, 1282-1287. [CrossRef] [PubMed]

87. Augustin, M.; Glaeske, G.; Radtke, M.; Christophers, E.; Reich, K.; Schäfer, I. Epidemiology and comorbidity of psoriasis in children. Br. J. Dermatol. 2010, 162, 633-636. [CrossRef]

88. Matusiewicz, D.; Koerber, A.; Schadendorf, D.; Wasem, J.; Neumann, A. Childhood psoriasis-An analysis of German health insurance data. Pediatric Dermatol. 2014, 31, 8-13. [CrossRef]

89. Mercy, K.M.; Paller, A.S. The relationship between obesity and psoriasis in the pediatric population: Implications and future directions. Cutis 2013, 92, 107.

90. Paller, A.S.; Mercy, K.; Kwasny, M.J.; Choon, S.E.; Cordoro, K.M.; Girolomoni, G.; Menter, A.; Tom, W.L.; Mahoney, A.M.; Oostveen, A.M. Association of pediatric psoriasis severity with excess and central adiposity: An international cross-sectional study. JAMA Dermatol. 2013, 149, 166-176. [CrossRef]

91. Swerlick, R.A.; Zhang, C.; Patel, A.; Chren, M.M.; Chen, S. The Skindex-mini: A streamlined QOL measurement tool suitable for routine use in clinic. J. Am. Acad. Dermatol. 2018, in press. [CrossRef]

92. Oostveen, A.M.; Spillekom-van Koulil, S.; Otero, M.E.; Klompmaker, W.; Evers, A.W.; Seyger, M.M. Development and design of a multidisciplinary training program for outpatient children and adolescents with psoriasis and their parents. J. Dermatol. Treat. 2013, 24, 60-63. [CrossRef] [PubMed]

93. Gonzalez, J.; Cunningham, K.; Perlmutter, J.; Gottlieb, A. Systematic review of health-related quality of life in adolescents with psoriasis. Dermatology 2016, 232, 541-549. [CrossRef] [PubMed]

94. LeBovidge, J.S.; Elverson, W.; Timmons, K.G.; Hawryluk, E.B.; Rea, C.; Lee, M.; Schneider, L.C. Multidisciplinary interventions in the management of atopic dermatitis. J. Allergy Clin. Immunol. 2016, 138, 325-334. [CrossRef] [PubMed]

95. Ricci, G.; Bendandi, B.; Aiazzi, R.; Patrizi, A.; Masi, M. Three years of Italian experience of an educational program for parents of young children affected by atopic dermatitis: Improving knowledge produces lower anxiety levels in parents of children with atopic dermatitis. Pediatric Dermatol. 2009, 26, 1-5. [CrossRef]

96. Barbarot, S.; Stalder, J. Therapeutic patient education in atopic eczema. Br. J. Dermatol. 2014, 170, 44-48. [CrossRef]

97. Premerlani, M.; Ludewig, Y.; Schnopp, C.; Ring, J. Eczema school: Practical approaches in an efficient module of tertiary prevention programs. In Handbook of Atopic Eczema; Springer: Berlin/Heidelberg, Germany, 2006; pp. 576-581.

98. Williams, H.C. Educational programmes for young people with eczema. Br. Med J. Publ. Group 2006, 332, 923-924. [CrossRef]

99. Wollenberg, A.; Barbarot, S.; Bieber, T.; Christen-Zaech, S.; Deleuran, M.; Fink-Wagner, A.; Gieler, U.; Girolomoni, G.; Lau, S.; Muraro, A. Consensus-based European guidelines for treatment of atopic eczema (atopic dermatitis) in adults and children: Part II. J. Eur. Acad. Dermatol. Venereol. 2018, 32, 850-878. [CrossRef]

100. Takaoka, R.; Aoki, V.; Campos, T. Support groups for patients with atopic dermatitis: A nine-year experience. Dermatol. Psychosom. 2000, 1, 33-38.

101. Fox, F.E.; Rumsey, N.; Morris, M. “Ur skin is the thing that everyone sees and you cant change it!": Exploring the appearance-related concerns of young people with psoriasis. Dev. Neurorehabilit. 2007, 10, 133-141. [CrossRef]

(C) 2019 by the authors. Licensee MDPI, Basel, Switzerland. This article is an open access article distributed under the terms and conditions of the Creative Commons Attribution (CC BY) license (http://creativecommons.org/licenses/by/4.0/). 